\title{
Bölgesel Güvenlik Kompleksi Teorisi Bağlamında Türkiye-İran Arasında Göç ve Sınır Güvenliği
}

\author{
Fikret Birdișli* \\ Merve Gören**
}

\section{Öz}

Soğuk Savaş sonrası uluslararası alanın geleceği ile ilgili öne sürülen tezlerden biri de Kopenhag Ekolü bağlamında geliştirilen Bölgesel Güvenlik Kompleksi Teorisidir (RSCT). Bu teoriye göre dünya ortak sorunlara sahip, iç dinamikleri açısından göreceli olarak homojen alanların oluşturduğu güvenlik bölgelerine ayrılabilir. Uluslararası alanın yeni çatışma alanları ve dinamikleri de bölge içi ya da bölgeler arası gerilimlerden kaynaklanacaktır. Bu kapsamda tanımlanan bölgelerden biri de Ortadoğu Güvenlik Kompleksidir. İran ve Türkiye aynı coğrafyada yer alan ortak sınırlara sahip iki komşu devlet olmalarına karşın bu teoride öznel nitelikleri dikkate alınarak farklı tanımlanmıştır. Buna göre İran Ortadoğu Güvenlik Kompleksinin lokal bir ülkesi iken Türkiye Ortadoğu ve Batı arasında yalıtkan bir ülke olarak bulunmaktadır. Teoride bölge içi güvenlik dinamikleri analiz edilirken bölgelerarası yalıtkan ülkeler ile lokal ülkeler arasındaki ilişki tam olarak açıklanmamıştır. Buradan yola çıkarak bu makalede Türkiye ve İran arasındaki güvenlik sorunları göç ve sınır güvenliği üzerinden incelenmiş, bu yolla lokal ve yalıtkan ülkeler arasındaki ilişkinin açıklanması amaçlanmıştır. Araştırmanın sonunda elde edilen bulgulara göre Türkiye ve İran arasındaki göç ve sınır güvenliği sorunları iki ülke arasındaki çatışan ilişkilere dayalı olmaktan çok Bölge içindeki konumlarına uygun bir niteliğe sahiptir.

Anahtar Kavramlar: Bölgesel Güvenlik. Göç, İran, Ortadoğu, Sınır Güvenliği

\footnotetext{
* Doç. Dr. Kahramanmaraş Sütçü İmam Üniversitesi, Siyaset Bilimi ve Uluslararası İlişkiler Böl. Öğretim Üyesi, fikretbirdisli@hotmail.com

** Yüksek Lisans Öğrencisi, Kahramanmaraş Sütçü İmam Üniversitesi, Siyaset Bilimi ve Uluslararası İlişkiler Böl. mervegören380@gmail.com
} 


\title{
Migration and Border Security Between Turkey and Iran in the Context of Regional Security Complex Theory
}

\author{
Fikret Birdișli* \\ Merve Gören**
}

\begin{abstract}
One of the most prominent theories about post Cold War Time is Regional Security Complex Theory (RSCT) that developed by Copenhagen School. According to this theory, the world could be divided to the regions which have common problems and homogeneous in internal dynamics. In this context, new conflicts areas and dynamics of international area are will originated from regional or interregional tensions.

The Middle East Security Complex is a one of these regions that based on this theory. Turkey and Iran has been defined in different category because of their sui generis positions even they are at the same region. So, Iran is local country and Turkey is isolator country in this complex according to the RSCT. Nevertheless, the relation between two kinds of state is not explained in the theory distinctly. Therefore this research aimed to examine the relationship between such as local and isolator countries in the context of border security of Turkey and Iran. According to the findings, border security problems and security relationship between Turkey and Iran are depends on their position that is explained in the theory, instead of conflicted interest.
\end{abstract}

Keywords: Border Security, Immigration, Iran, Middle East, Regional Security

Assoc.Prof.Dr. Kahramanmaras Sutcu Imam University, Political Science and International Relation, fikretbirdisli@hotmail.com

** Master Student, Kahramanmaras Sutcu Imam University, Political Science and International Relation, mervegören380@gmail.com 


\section{Giriş $^{1}$}

Soğuk Savaş sonrası uluslararası ortam hakkında öngörüler içeren teorilerden biri de Paul Samuel Huntington'un Medeniyetler Çatışması teziydi. Gördüğ̈̈ ilgi kadar tartışmalara da yol açan bu tez, Kopenhag Ekolü akademisyenleri tarafından yetersiz görülerek Soğuk Savaş sonrası dönemde güvenlik sorunlarının medeniyetler arası değil bölgeler arası ve/veya bölge içi çatışmalardan kaynaklanacağı ileri sürülmüştür. Bu doğrultuda geliştirilen teoriye Bölgesel Güvenlik Kompleksi Teorisi (Regional Security Complex Theory/RSCT) denilmektedir. ${ }^{2} \mathrm{Bu}$ teoriye göre güvenlik açısından benzer sorunlar yaşayan ya da bu konularda ortak potansiyele sahip olan coğrafi alanlar bir kompleks oluşturur. Bu tanım kapsamında Ortadoğu bölgesi üç sub-kompleksten oluşan bir bölgesel kompleks olarak uluslararası güvenlik açısından büyük önem taşır.

Ortadoğu coğrafyasının sınırları konusunda farklı yaklaşımlara dayalı tanımlar bulunmaktadır. Bu farklılıkların temel nedeni öncelikle dünyanın yuvarlak olması, dolayısıyla referanslara göre yön tanımlamasının da değişebilmesidir. Bu nedenle tarihsel anlatımlarda coğrafi tanımlamanın da daha çok medeniyet merkezli yapıldığı fark edilir. Örneğin Heredot, tarihi -Antik Yunan ve Persler'i kast ederek- Doğu ve Batı arasındaki efsanevi düşmanlığa dayalı bir önsöz (preface) olarak nitelerken, bu anlatımında Ege kıyılarını coğrafi bir merkez olarak ele aldığı anlaşılmaktadır. ${ }^{3}$ Ortaçağ Avrupa'sında ise Doğu ve Batı arasındaki ayrımda merkez rolünü bu kez yani Bizans üstlenmiştir. ${ }^{4} \mathrm{Bu}$ doğrultuda daha öznel bir amaca yönelik olarak Ortadoğu kavramının kullanımına ise Napolyon'un Mısır seferi (1789-1801) sırasinda rastlamaktayız. ${ }^{5}$ Fakat tüm bu tanımlamalar 19'ncu yüzyıla gelene kadar coğrafi içeriğin dışına taşmamış 1890 'lardan itibaren

Bu çalışmanın kısa özeti, 12-14 Ekim 2017'de Kahramanmaraş Sütçü İmam Üniversitesinde düzenlenen 1'nci Uluslararası Kahramanmaraş Yönetim Ekonomi ve Siyaset Kongresinde sözlü bildiri olarak sunulmuştur.

2 Barry Buzan ve Ole Waver, Regions and Powers: The Structure of International Security, Cambridge: Cambridge University Press. 2003, p.44.

3 Robert Irwin, Oryantalistler ve Düşmanları, (çev. Bahar Tırnakçı), İstanbul: Yapı Kredi Yayınları, 2008,18

4 Andreas Pflitsch, Mythos Orient Eine Entdeckungsreise, Basel: Herder, Freiburg 2003, p.11.

5 Anja Jedlitschka, Weibliche Emanzipation in Orient und Okzident. Von der Unmöglichkeit, die Andere zu befreien, Würzburg: Ergon Verlag, 2004, p.22. 
ise sömürgeci Avrupalı güçlerin stratejik planları doğrultusunda kavramın içinde jeopolitik konsept ön plana çıkmıştır. Bu kapsamda bölge ile ilgili ilk dikkat çeken tanımlama ise İngilizlerin kullandığı Yakındoğu (Near East) kavramıdır.

İngilizlere göre Yakındoğu, Balkanları da içeren bir sınırdan başlayarak Osmanlı coğrafyasını içermekte, uzak doğu kavramı ise Hindistan ve civarına işaret etmektedir. ${ }^{6}$ Ortadoğu'ya modern anlamını kazandıranlar ise Amerikalılar olmuştur. Amerikalı jeopolitika uzmanı Alfred Mahan'a göre Ortadoğu, Süveyş Kanalı'ndan başlayıp Singapur'a kadar uzanmaktadır. ${ }^{7}$

Çağdaş kullanımda Ortadoğu kavramı ise Güneyde Etiyopya, Kuzeyde Türkiye, Doğuda Afganistan ve Pakistan, Batı'da ise Fas'ı içeren geniş bir coğrafyaya işaret etmektedir. ${ }^{8}$ Ayrıca pek çok çalışmada Ortadoğu bölgesinin jeopolitik ihtiyaçlar doğrultusunda alt bölgelere ayrıldığını da görmekteyiz. ${ }^{9}$

$\mathrm{Bu}$ çalışmada teorik referans olarak alınan Bölgesel Güvenlik Teorisinde ise Ortadoğu bölgesi, güvenlik paterni ve kültürel nitelikler dikkate al1narak Fas'tan İran'a kadar ve İsrail'i de içerecek biçimde çerçevelenerek tanımlanmıştır. Bu tanımlama içinde Batı'da Türkiye, Doğu'da ise Afganistan yalıtkan (insulator) ülkeler olarak isimlendirilmiştir. ${ }^{10} \mathrm{Bu}$ teori kapsamında Türkiye-İran ilişkilerini konuştuğumuzda, izolatör bir ülke ile lokal bir ülkeden söz ediyoruz demektir. Belki de bu nedenle Türkiye ve İran dünyanın en fazla geçişkenliğe sahip beş bölgesinden biri olarak iki kıtayı birbirinden ayıran sınırları paylaşmaktadırlar. Yine bu nedenle Ortadoğu'da iki bölgesel güç olan İran ve Türkiye, farklı jeopolitik, ekonomik ve kültürel gerçekliğe dayalı olarak yürüttükleri ikili ilişkilerinde ontolojik çelişkiler barındırmaktadır.

6 Bernard Lewis, The Middle East and the West, London: Weidenfeld and Nicolson, 1968,p.10.

7 Roderic, Davison, "Where is The Middle East?" In The Modern Middle East, edited by Richard H. Nolte, pp. 13-30, New York: Atherton, 1963, p.17.

8 Margret Johansenn, Der Nahost-Konflikt: Eine Einführung, Wiesbaden, Springer VS, 2006, p11

9 Osman Nuri Özalp, "Where is the Middle East?The Definition and Clasification problem of Middle East as a Regional subsystem in International Relations", Turkish Journal of Politics, v.2, issue 2, 2011, p. 11

10 Buzan And Weaver,2011, p.187 
Bu makalenin amacı Bölgesel Güvenlik Teorisi'nin yapmış olduğu niteliksel tanımlama üzerinden Türkiye-İran ilişkilerini irdelemek için sınır güvenliği sorunlarına odaklanmaktır. Böylelikle aynı coğrafya içinde yer almalarına rağmen yalıtkan-lokal olarak tanımlanan iki ülke arasındaki jeopolitik farklılığın sahaya olan yansıması Türkiye ve İran ilişkileri üzerinden açıklanmış ve örneklenmiş olacaktır. Ayrıca sınır güvenliğinin önemli bir unsuru olan göç olgusu günümüz uluslararası alanın temel güvenlik sorunlarından biridir. İran ve Türkiye ise Doğudan Batıya doğru akan en büyük göç yollarından birinin üzerinde olması nedeniyle uluslararası güvenliğin bir öznesi haline gelmişlerdir. Bu açıdan iki ülkenin sınır güvenliği konusundaki sorunları artık Bölgeyi aşan bir nitelik ve önem taşımaktadır.

$\mathrm{Bu}$ kapsamda makalenin teorik arka planı Kopenhag Ekolü tarafindan geliştirilen Bölgesel Güvenlik Kompleksi Teorisi ve Sektörel Güvenlik yaklaşımına dayandırılıştır. Betimsel analiz yöntemlerinin kullanıldığı bu çalışmada göç ve sınır güvenliği ile ilgili analizler için açık ve resmi kaynaklardan elde edilen istatistiksel verilerden yararlanılmıştır.

\section{Bölgesel Güvenlik Kompleksi Teorisi}

Kopenhag Ekolü'nün önde gelen teorisyenlerinden Barry Buzan'ın Bölgesel Güvenlik Kompleksi Teorisi uluslararası ilişkilerde inşacı yaklaşım için önemli referanslar barındırır. ${ }^{11}$

Buzan ilk defa 'People, State and Fear"isimli kitabında RSCT'ye yer vermiş, Soğuk Savaş sonrası uluslararası sistemin nasıl bir hal alacağ tartışmalarına farklı bir bakış kazandırmıştır. Ayrıca Buzan bu teorisiyle Soğuk Savaş sonrası için ileri sürülen tezlerden biri olan Paul Huntington'un "Medeniyetler Çatışması" savına bir eleştiri getirerek farklı bir alternatif sunmuştur. ${ }^{12}$ Çünkü Buzan'a göre uluslararası sistemde yeni çatışma ya da ittifaklar küresel, kültürel, dinsel ya da medeniyetler bağlamında yaşanan farkl1lıklar ekseninde değil bölgeler içinde yer alan alt sistemlerde yaşanan güvenlik etkileşimleri bağlamında bölgeler ekseninde gerçekleşecektir. Bu teoride temel düşünce, bölge içinde yer alan ülkelerin birbirlerini tehdit

\footnotetext{
11 Aslan Yavuz Şir, "Bölgesel Güvenlik Kompleksi Teorisi, Enerji Güvenliği ve Rusya", Global Strateji Enstitüsü, 2003, s. 346.

12 Buzan and Waver, 2003, p.41
} 
olarak algılamasının bölge dışındaki ülkelere algıladıkları tehditlere kıyasla daha fazla olmasına dayandırılmıştır. ${ }^{13}$

Buzan'ın önerdiği RSCT'ye göre bir güvenlik kompleksinin oluşmasında veya bölge ülkelerinin bir güvenlik sistemini oluşturmasında rol oynayan faktörler şunlardır:

i. Ülkelerin coğrafik konumlarının birbirlerine olan yakınlığ

ii. Bölge içinde yer alan devletlerin güvenliklerinin birbirleriyle bağlantılı olmas1

iii. Bölgede yer alan ülkeler arasında jeostratejik çıkarların örtüşmesi ve bu bağlamda karşılıklı güç ilişkileri ya da rekabetinin bulunması

iv. Bölge içinde yer alan ülkeler arasında komşuluk, savunma, destek, şüphe veya korku içeren güçlü ilişkilerin varlığ ${ }^{14}$

Bunun dışında Buzan ve arkadaşlarının içinde yer aldığı Kopenhag Ekolü, Soğuk Savaş sonrası dönemde güvenliğin yeni koruma alanlarını beş alt kategoride sınıflandırarak güvenlikleştirme (securitization) teorisi ile birlikte yeni bir uyarlama geliştirmişlerdir. ${ }^{15} \mathrm{Bu}$ beş sektör şunlardır:

a. Askeri Güvenlik (kuvvet temelli baskı ilişkileri)

b. Siyasi Güvenlik (iktidar, yönetim ilişkileri)

c. Ekonomik Güvenlik (ticaret, üretim, finans ilişkileri)

d. Sosyal Güvenlik (kimlik ile ilgili ilişkiler)

e. Çevresel Güvenlik (insan faaliyetleri ve gezegendeki çevre konuları) etrafinda toplanmıştır. ${ }^{16}$

RSCT'sine göre, bir bölgede yer alan her aktörün güvenliği aynı zamanda bölgede yer alan diğer aktörlerin güvenliği ile de yakından ilişkilidir. Do-

13 A.Y. Şir, "Bölgesel Güvenlik Kompleksi Teorisi”, Enerji Güvenliği ve Rusya,2003, s. 346.

14 Aygerim Şibelikova, “' Orta Asya Bölgesel Güvenlik Sistemine Doğru: Perspektifler”, T.C. Başbakanlık Atatürk Kültür, Dil ve Tarih Yüksek Kurumu, 2007, s. 1320.

15 Nebi Miş, "Güvenlikleştirme Teorisi ve Siyasal Olanın Güvenlikleştirilmesi", Akademik Incelemeler Dergisi, 2011, c./6, sy./2, s. 347.

16 Columba Peoples and Nick Voughan-Williams, "Securitisation Theory", Critical Security Studies, Routledge New York,2015, p.97 
laysıyla uluslararası ilişkiler açısından güç dengesi, kutuplaşma ve ittifak arayışları gibi stratejiler bölge bazında anlamlandırılabilir. Bir bölgenin güvenlik kompleksi olarak adlandırılabilmesi için önem taşıyan diğer bir husus da bölge içi aktörlerin ortak bir tehdit algılamasına sahip olmasıdır. Çünkü ortak tehdit algısı devletlerarası karşı1ıklı bağımlılık ilişkisini güçlendirecektir. Tarihsel dostluk-düşmanlık ilişkileri, çatışmalar, ihtiyaçların benzerliği ve ortak düşman gibi faktörler güvenlik kompleksinin şekillenmesinde kurucu rol oynar. ${ }^{17}$

\section{Sektörel Güvenlik Teorisi Bağlamında Göç ve Sınır Güvenliği}

RSCT'de yer alan güvenlik sektörleri, sektör içinde yer alan unsurların birbirleri ile olan ilişkilerini açıklayan birer betimleme olarak değerlendirilir. Ayrıca Buzan, bu sektörlerin her birinin birbirlerini tetikleyen birer süreç olarak dikkate alınmasının gerekliliğini de vurgular. ${ }^{18} \mathrm{Bu}$ nedenle, Buzan ve arkadaşları devlet merkezli ve adeta tek sektörlü güvenlik anlayışının mevcut güvenlik sorunlarını analiz etmede yetersiz kaldığını bu nedenle başka referans nesneler eklenmesinin zorunluluğundan söz eder. ${ }^{19}$

Sektörel Güvenlik Teorisinde yer alan Toplumsal Güvenlik (Societal Security), sosyal yapıyı oluşturan kurumlar ve değerlerin zaman içinde nası1 inşa edildikleri ve değişebildikleriyle yakından ilgilenir. Dolaysıyla toplumlar sosyal yapıyı zorlayan değişimlerin baskısı altında ontolojik güvenlik sorunları yaşayabilirler. Bu durumun ortaya çıkarttığı olgulardan biri de göçtür. ${ }^{20}$ Dolaysıyla göç ve iltica genel güvenlik anlayışı ile ilgili bir fenomendir. ${ }^{21}$ Çoğunlukla ontolojik güvenlik arayışının ortaya çıkardığ göç ve göçmenlik; politik, ekonomik içerikli gündelik konuşmalarda normal yaşamın akışını bozan bir "tehdit" olarak değerlendirildiğinde yeni bir güvenlik sorunu haline gelmektedir. Yani göç ve mültecilik sadece sıradan

17 Göktürk Tüysüzoğlu, “Güvenlik İsteminin Diş Politika Oluşum Sürecine Etkisi: Ermenistan-İran İlişkileri'nin Güvenlikleştirme Kuramı Bağlamında Anlamlandırılması", $O A K A$, c.8,s16, 2013, ss.95-123 2013, s. 10.

18 A.g.e. s. 11

19 Selim Kurt, “ Toplumsal Güvenliğin Yükselişı”, International Journal Of Social Science, 2015, Say1.37, s. 466.

$20 \quad$ Fikret Birdişli, Teori ve Pratikte Uluslararası Güvenlik, (3'ncü Baskı), Ankara Seçkin Yayınlar1, 2017, s.130

21 Jef Huysman'dan aktaran Selim Kurt s. 470 
insanların yaşamını alt üst eden bir olgu olmayıp yerleştikleri yeni toplumun kolektif yaşam biçimini de tehlikeye atan bir unsurdur. Bu nedenle güvenlik çalışmaları içinde göç olayına Toplumsal Güvenlik başlı̆̆ içinde yer verilmektedir ${ }^{22}$

Göçün tarihçesi, insanlık tarihi kadar eskidir. Coğrafi koşullar, ekonomik nedenler, toplumsal, siyasal gelişmeler, çatışma ve savaşlar gibi etkenlere bağlı olarak insanlar yer değiştirmekte ve çeşitli boyutlarda nüfus hareketlilikleri yaşanmaktadır. dolayısıyla nüfus hareketleri yüzyıllardır gerçekleşmeye devam etmektedir. Özellikle 1990'lı yıllarla başlayan, ancak 2000'li yıllarla artarak devam eden devletlerin içerisinde gerçekleşen çatışmalar, kendisini güvende hissetmeyen yüz binlerce insanın yaşamını sürdürebileceği güvenli bir yer arayışına girmesine neden olmaktadır. Uluslararası Göç Örgütü'nün 2015 tarihli raporuna göre, dünya üzerinde 232 milyon uluslararası göçmen yer almakta ve her geçen yıl artan bir göç olgusu dikkat çekmektedir. ${ }^{23}$

En yalın hali ile göç, "nedeni ve süresi ne olursa olsun bir ya da bir grup insanın yurt içinde ya da ülkeler arası yer değiştirmesi anlamına gelir". ${ }^{24}$ Daha açık bir ifade ile insanlar yaşadıkları koşulların baskısı karşısında bir tepki olarak ya da daha iyi yaşam koşullarına ulaşma arzusu ile yer değiştirebilirler. Bu durumda ülke içinde yerel yer değişimleri iç göç olarak adlandırılırken ulusal sınırlar ya da kıtalar arası yer değiştirme ise dış göç olarak tanımlanır. Göç olgusunun içerik genişliği nedeniyle öznel durumları birbirinden ayırmak üzere mülteci, sığınmacı ve göçmen gibi farklı kavramlar kullanılmaktadır ${ }^{25}$

Göç ve iltica sorunları 1951 Cenevre Sözleşmesi'yle beraber uluslararası yeni bir boyut kazanmıştır. Bireylerin bir takım nedenlerle hayati tehlikesi söz konusu iken bu durumun giderilmesi iltica (siyasi sığınma) hakkını doğurmuş ve iltica rejimi uluslararası kurumlar vasıtasıyla düzenlenmeye

\footnotetext{
22 Kurt, “Toplumsal Güvenliğin Yükselişi”, s. 470.

23 Gonca Oğuz Gök, "Kimin Güvenliği? Uluslararası Göç-Güvenlik İlişkisi ve Uluslararası Örgütlerin Rolü’, KOSBED, 2016, sy./31, s. 66.

24 Birdişli, 2017, s.266

25 Yılmaz Demirhan ve Seyfettin Aslan, 'Türkiye'nin Sınır Ötesi Göç Politikaları ve Yönetimi”, Birey ve Toplum Dergisi, 2015, c./5, sy./9, s. 25.
} 
çalışılmıştır. Ekonomik sebeplerle göç etme ve göçün neden olduğu sorunlarla uğraşma konusu ise devletlerin iç hukukuna bırakılmıştır. ${ }^{26}$

Siyaset Bilimi alanında göç çalışmalarının tarihi ise çok derin sayılmaz. 1990 sonrası dönemde artan göç oranları ve göçün hem gelişmiş hem de gelişmekte olan ülkeler üzerindeki etkileri ve neden olduğu sorunların çeşitliliği göçün "güvenlik" boyutunu içeren kapsamlı bir alan yazınının ortaya çıkmasına neden olmuştur. Bu çalışmalar içinde Hollified'in göç konusunda ulus devletlerin rolünü öne çıkaran çalışmaları bu makalenin konusu açısından önem taşır. Çünkü Hollified, göç akışlarını engelleme ve sinırları denetleme hususunda ulus devletlerin rolünün önemli bir konu haline geldiğini vurgulamaktadır. Bir başka deyişle, temel mesele ulus devletlerin ülkelere giriş çıkışların kurallarını belirlemedeki rolüdür. ${ }^{27}$

Göç sorununu ulusal planda irdeleyen çalışmaların yanı sıra konuyu daha geniş planda ele alan yaklaşım ve uygulamalar da önemlidir. Bunlar arasında göç sorununa yönelik uluslararası ve bölgesel politikalar geliştiren örgütlerden biri olarak Avrupa Birliği (AB) hem konuya ulus devleti aşan bir yaklaşım geliştirmesi hem de Türkiye'nin üyelik çabaları açısından ayrı bir önem taşımaktadır. Ayrıca AB, serbest dolaşımı ortaklığın temel ilke ve hedeflerinden biri olarak gördügü için göç konusuna özel bir önem vermek durumunda kalmıştır. ${ }^{28}$ Üyeliğe aday devletlerden biri olan Türkiye ise göç konusunda gerek tarihsel tecrübeleri ve gerekse jeopolitik konumu nedeniyle $\mathrm{AB}$ açısından, başlı başına dikkat çeken ve üzerinde durulması gereken bir ülke konumundadır . ${ }^{29}$

Göç ve sınırlar konusunda pratik uygulamaların yanı sıra teoride de farklı yaklaşımlar yer almaktadır. Bu kapsamda konuya eleştirel bir bakış Güvenlikleştirme (Securitization) teorisinde yer almaktadır. Bu teoride "devlet güvenliğinden ulus kimliğinin korunmasına doğru yeni bir güvenlikleştirme sürecinin olduğu" tartış1makta ve bu sürecin sınır güvenliğine

26 İbrahim Karaca, 'AB'nin Entegre Sınır Yönetimi Kurumu Frontex'in Rolü ve Türkiye'nin Uyum Süreci”, Yüksek Lisans Tezi, T.C. Beykent Üniversitesi, 2016, İstanbul, s. 17.

27 G.O. Gök, "Kimin Güvenliği? Uluslararası Göç-Güvenlik İlişkisi ve Uluslararası Örgütlerin Rolü”,KOSBED, s.31 s. 68.

28 Yılmaz Demirhan ve Seyfettin Aslan, “Türkiye'nin Sınır Ötesi Göç Politikaları ve Yönetimi”, Birey ve Toplum, 2015, c.5,say1 9, s. 31.

29 A.g.e, s. 34. 
yeni anlamlar kattığı anlatılmaktadır. Bu doğrultuda Güvenlikleştirme Teorisinde sınırlar dost ve düşmanı ayır eden bir çizgi şeklinde realist bir yaklaşımla tanımlanmıştır. ${ }^{30}$

Pek çok yerde sınırlar bir ülkeyi diğerinin kara ve deniz varlıklarından ayıran siyasal/hukuksal hatlar olarak ele alınır. Bu coğrafik ayrışmanın ötesinde sınırlar egemenlik haklarının başlangıç ve bitiş yerlerini göstermesi açısından da yetkisel bir hattır. Bu nedenle sınırlar arasında yer alan kontrol noktaları ülkesel egemenliğin çeşitli düzenlemeler bağlamında tezahür ettiği özel mekânlar olarak da kendini gösterir. ${ }^{31}$ Çünkü ülkelerin yüz yüze kaldıkları tehditlerin niteliği ve bu bağlamda geliştirmiş oldukları düzenlemeler öncelikle sınırlarda ve sınır kontrol noktalarında kendini gösterir. $\mathrm{Bu}$ nedenle sınırlar ulusal güvenliğin sağlandığı ön hatlar olarak düşünülmektedir. $^{32}$

$\mathrm{Bu}$ yaklaşım ve uygulamaların yanı sıra göçün güvenlikle olan ilişkisinin sınır güvenliğinin de ötesine geçerek iç politikada da bir tartışma konusu olduğu görülmektedir. Örneğin bazı partiler göç karşıtı söylemlerini parti ya da seçim programlarına ekleyerek sloganlar ve söylevler yoluyla göçü iç politika malzemesi haline getirmektedir. Böylelikle iltica taleplerinin kabulü, yerleşim ve vatandaşlık hakkının verilmesi, çalışma izinleri ve buna ilişkin kotalar, yabancıların kayıt usulleri ve gereklilikleri sadece birer idari, siyasi ve hukuki işlem niteliğinin ötesine geçerek algısal bir güvenlik sorunu haline getirilebilmektedir. ${ }^{33}$

Buraya kadar yapılan genel açıklamalar ve farklı örneklerden yola çıkarsak göç konusunun çok boyutlu ve her alanda alabildiğine derinleştirilmesi mümkün olan bir fenomen olduğu kendiliğinden ortaya çıkar. Bu nedenle göç ve sınırlar konusu coğrafi, sosyolojik ve politik içerikler taşıyan, hatta belli bir sosyalizasyon süreci sonunda ulusal ve uluslararası politikaya

30 Ahmet Kaya, "Sınır Güvenliği Paradigmalarındaki Değişim ve Türkiye'nin Sınır Güvenliği Yapısının Analizi”, Uluslararası Güvenlik ve Terörizm Dergisi, 2013, sy./4, s. 3.

31 Ahmet Kaya, “Avrupa Birliği’nin Yasadışı Göçle Mücadele Politikası ve Türkiye Üzerindeki Etkileri”, Yüksek Lisans Tezi, T.C. Ankara Üniversitesi, 2005, s. 8.

32 Murat Yeşiltaş, 'İç Savaşta Komşu Olmak Türkiye'nin Suriye Sınır Güvenliği Siyaseti”, SETA Analiz, 2015, say1./136, s. 11.

33 Nazif Mandacı ve Gökay Özerim, "Uluslararası Göçlerin Bir Güvenlik Konusuna Dönüşümü: Avrupa'da Radikal Sağ Partiler ve Göçün Güvenlikleştirilmesi”, Uluslararası İlişkiler Dergisi, 2013, c.10, sayı.39, s. 112. 
eklemlenebilen bir olgu olarak uluslararası ilişkiler alan çalışmalarında yerini korumaya devam etmektedir. Konunun geniş ve farklı boyutları bir kenara bırakılarak bu makalenin konusu ve kapsamı nedeniyle göç olgusuna sınır güvenliği açısından odaklanılacağ 1 için konuya teorik bir arka plan olarak RSCT tercih edilmiştir.

\section{Ortadoğu Güvenlik Kompleksinde Türkiye ve İran'ın Konumu}

RSCT ile ilgili yukarıda yapılan açıklamalarda İran'ın Ortadoğu güvenlik kompleksi içinde yer almasına karşın Türkiye'nin bu teoride kompleksler arası izolatör bir ülke olarak tanımlandığ 1 vurgulanmıştı. Türkiye'nin tüm Ortadoğu coğrafyasıyla olan ilişkisi İmparatorluk dönemine dayanan köklü bir geçmişe sahip olmasına rağmen Cumhuriyet dönemi sıkı biçimde takip edilen Batıcılık politikası ve iki kutuplu yapılanmanın getirdiği asimetrik ilişkiler nedeniyle yakın tarihe kadar Türkiye'nin Ortadoğu ile ilişkileri göreceli olarak düşük düzeyde seyretmiştir. Ayrıca Türkiye, İslam ülkeleri arasında laikliği bir devlet politikası olarak benimseyen tek ülke olması nedeniyle Ortadoğu'da yer alan diğer ülkelerden ayrılırken, laikliği yorumlayış biçimi de Türkiye'nin İslam ülkeleri ile olan ilişkisini zayıflatmıştır.

Tanımlanan bu coğrafya içinde sömürge olmamış olan ülkeler Türkiye, Suudi Arabistan ve İran'dır. Günümüzde Ortadoğu dünyasının pek çok problemi de sömürge dönemlerinin bir mirasıdır. Ayrıca Güney Asya bölgesinde olduğu gibi Ortadoğu bölgesindeki pek çok devlet de savaş ve çatışmalara dayalı gerilimden doğmuştur. Fakat Güney Asya bölgesi iki büyük güç arasında cereyan eden tek bir rekabete sahne iken, Ortadoğu'da güçleri birbirine yakın yirmi kadar ülke arasında sürekli bir rekabet bulunmaktadır. Buzan'ın yaptığı sınıflandırmaya göre bölgedeki çatışma potansiyeli Suudi ve Haşimi monarşilerine dayalı Araplar arası, Arap liderliği iddiasına dayalı Irak ve Misır arası, toprak ve egemenlik iddialarına dayalı Filistin-İsrail arası olmak üzere üç farklı kategoride akut nitelikler taşır. ${ }^{34}$

Bu kapsamda Ortadoğu Bölgesel Kompleksi Levant, Körfez ve Mağrip merkezli olmak üzere üç alt kompleksten oluşmuştur. Somali, Cibuti ve Sudan gibi ülkeler Ortadoğu Güvenlik kompleksiyle ilişkili olmakla bir-

34 Buzan ve Waver, 2003, p.187 
likte Afrika alt kompleksine ait olduğu düşünülmektedir. Bölgenin tarihsel uzlaşmazlık dinamiği Osmanlı'nın son dönemlerinde Türklere karşı Araplar şeklinde işlerken artık İran'a karşı Araplar şeklindedir. İkinci Dünya Savaşı sonrasında yükselen Arap milliyetçiliği daha çok Araplar arasında rekabeti körüklemiştir. Bunun tek istisnası Arap-Fars rekabetini körükleyen İran-Irak savaşı ve İsrail'e karşı ortak duruşlarına rağmen Suriye/ Ürdün ikilisinin Filistin'le olan anlaşmazlıklarıdır. Tüm bu dinamikler Bölgesel Güvenlik Kompleksi'nin kıvrak ve kesişen bir karaktere sahip olduğunun delilleridirler. ${ }^{35}$

Birinci Dünya Savaşı'nın ardından Türkiye ve İran'ın bağımsız olmakla birlikte yüzü Batıya dönük politikalar izlemesi bu iki ülkenin bir süreliğine bölgenin sık değişen dinamiklerinin dışında kalmalarına yardım etmiştir. İran-Irak savaşı sırasında ise körfez Arap ülkeleri bu iki ülkeyi dışarıda bırakarak ortak işbirliğine gitmişlerdir. İran'da yaşanan İslam devrimi ise Suudi Arabistan-İran arasındaki ilişkiyi din temeline dayalı keskin bir rekabete dönüştürmüştür.

Türkiye'nin bölge içindeki konumu Kopenhag Ekolü tarafından yalıtıcı (insulator) ülke olarak tanımlanmaktadır. Türkiye resmi olarak bu tanımı kabul etmemekte kendisini bir Avrasya ülkesi, Doğu ve Batı arasında köprü ya da son zamanlarda olduğu gibi farklı kültürler arasında bir merkez ülke olarak konumlandırmaktadır ${ }^{36}$. Buna karşın Kopenhag Ekolü düşünürlerine göre Türkiye'nin bölge içinde merkez bir ülke rolü oynayabilmesi ise ekonomik ve siyasal kapasitesini geliştirmesine bağlıdır. ${ }^{37}$

İran ise yakın tarihi boyunca farklı bir yol izlemiştir. İran'ın ortadoğu kompleksi içinde yer alan Arap ülkeleri ile tarihsel nedenlere dayalı, daha çok kültürel içerikli bir rekabeti bulunduğu görülmektedir. İran'da 1979'da yaşanan devrim sonrası bu rekabet dini argümanları daha yoğunlukla ve resmi bir biçimde içerecek şekilde derinleşmiştir. Bu açıdan Ortadoğu Güvenlik Kompleksinde yer alan "Arapların-Arap olmayanlara karşı” ve "Arapların-Araplara karşı" olan çatışma dinamiğinde İran "Arap-Arap ol-

\footnotetext{
A.g.e

Ahmet Davudoğlu, Stratejik Derinlik, İstanbul: Küre Yayınları, 2002, s.65 ve Dış İşleri Bakanlığ1 Web sayfası, http://www.mfa.gov.tr/genel-gorunum.tr.mfa

37 Barry Buzan ve Ole Weaver, Regions and Powers The Structure Of International Security,2000, s. 394.
} 
mayan" kategorisinin en önde gelen temsilcisidir. Buna karşın değişen koşullar gereği bu dinamiğin farklı işlediği anlar da olmuştur. Örneğin İranIrak savaşında Suriye bir Arap ülkesi olmasına karşın İran'la ittifak halinde olmuştur. Fakat gerçekte bu durum konjonktüreldir. ${ }^{38}$

\section{Göç ve Sınır Güvenliği Açısından Türkiye-İran İlişkileri}

Türkiye ve İran arasındaki ilişkiler göç ve sınır güvenliği bağlamında ele alındığında her iki ülke arasında yer alan sınırın coğrafik nitelikleri ve her iki ülkenin sınır kontrolü üzerindeki sorumlulukları öne çıkmaktadır. Bu nedenle konu bu iki başlık altında irdelenmektedir.

\section{İran-Türkiye Sınırının Jeopolitiği}

İran Türkiye sınırı $560 \mathrm{~km}$. ile Türkiye'nin en uzun sınırlarından biri olup iki ülke sınırları 1639'da imzalanan Kasr-1 Şirin anlaşması ile belirlenmiştir. Bu haliyle Türkiye-İran sınırı Avrupa'nın en eski sınırını oluşturmaktadır. Türkiye'den İran Azerbaycan'ına Erzurum-Doğu Beyazıt- Tebriz karayolu ile geçilmektedir. Türkiye-İran sınırının geçtiği yerler Urmiye Gölü ile Aras Nehrine öte yandan Van Gölü ile Murat Nehri ve Dicle'ye akan suların bulunduğu aynı zamanda dağlık olan bir alandır. Bu sınır, Ağrı dağlarının doğusundan başlar güneye doğru 2500 metre irtifaya ulaşır ve daha yüksek dağlardan geçer. Van'ın doğusundan olmak üzere Van-ErçekÖzalp ile İran'daki Kotur arasındaki çukurca yerler ve buralarda yer alan vadilerden Van-Özalp1-Kotur karayolu geçmektedir. Bu sınırın kuzeyinde Doğubeyazıt, Mako arasında çok işlek bir sınır kapısı olan Gürbulak gümrük kapısı yer almaktadır. Bu gümrük kapısı uluslararası karayolunu denetler. Daha güneyde ise Başkale ve İran'daki Dilman arasında başka bir geçit bulunmaktadır. Ancak buradaki karayolu Başkale-Yüksekova üzerinden Türkiye-Han hududundaki Esendere Gümrük Kapısına ulaşır ve İran Han'da bulunan Urimiye şehrine ulaşır. Buradan itibaren giderek artan dağlık kesimden sonra ise Türkiye-Irak sınırı başlar. Bu sınır, bölgenin en sarp dağları olan Sat ve Cilo Dağı ile daha batıda yer alan dağlık yerlerin güneyinden devam eder, uzanır. ${ }^{39}$

\footnotetext{
$38 \quad$ A.g.e s. 190

39 “Türkiyenin Sınırları”, Ekodialog, 2017.
} 
Türkiye ve İran arasında aktif üç sınır kapısı bulunmaktadır. Bunlar: AğrıDoğubayazıt'ta bulunan Gürbulak sınır kapıs1; Van-Özalp'ta bulunan Kapıköy sınır kapısı; Hakkari-Yüksekova'da bulunan Esendere Sınır kapısıdir (Harita 1).

Harita 1'de gösterilen bu sınır kapıları coğrafyanın geçişe izin verdiği yerlerde oluşturulmuştur. Bu sınır kapılarından Van'da bulunan Kapıköy sınır kapısı sadece küçük araçlar için geçiş sağlamaktadır. Gürbulak sınır kapısı ise tarihi ipek yolu üzerinde bulunmak ve Türkiye-İran sınırının en önemli sınır kapısı olarak işlev görmektedir.

Harita 1. Türkiye-İran Sınırında Bulunan Sınır Kapıları ve Geçiş Noktalar $^{40}$

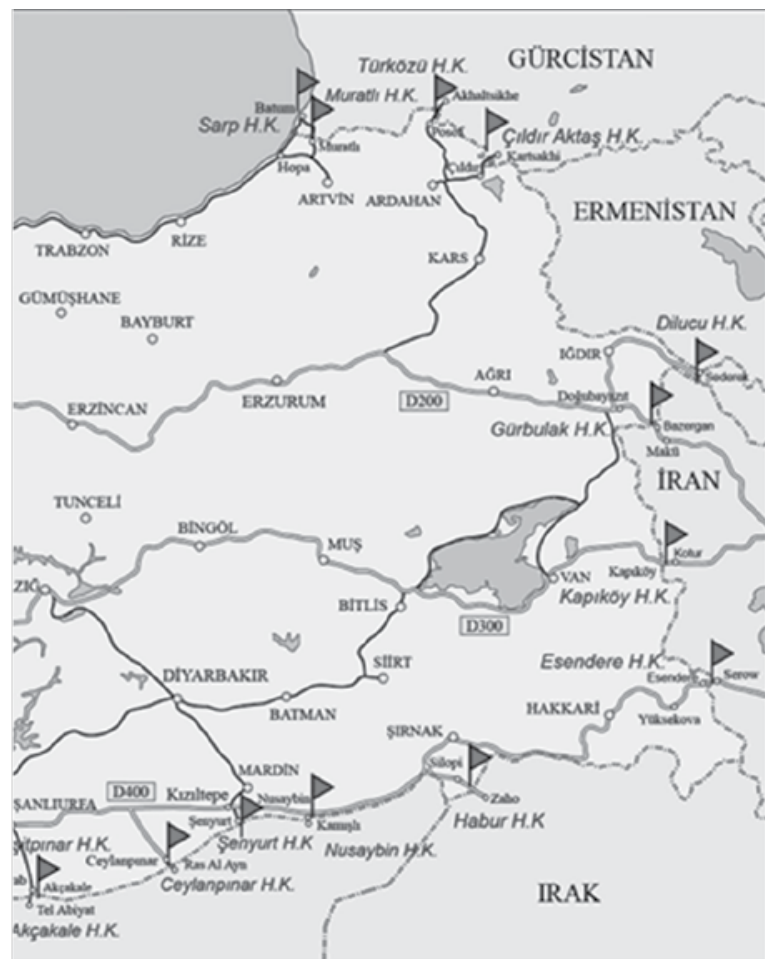

$40 \mathrm{http} / /$ cografyaharita.com/turkiye_ulasim_haritalari.html,https://ggm.gtb.gov.tr/ gumruk-idareleri/hudut-kapilari/kara-hudut-kapilari 
Türkiye İran sınırını 1913 yılında İngiltere yeniden belirlemiş 1926 ve 1927 y1llarında bu sınırda yaşanan sorunları çözmek için karşılıklı çalışmalar yürütülmüştür. 1929 yılında ise iki ülke arasında karma bir komisyon oluşturulmuştur. Komisyonun çalışmaları sonucu 1932 yılında uzlaşmaya varılan ilk anlaşma ile Küçük Ağrı Türkiye'ye bırakılmış bunun karş1lığ1 olarak güneyde bir kısım toprak parçası İran'a bırakılmıştır. ${ }^{41}$

Türkiye İran arasında sınır hattının coğrafi yapısı sınır güvenliğini ve alan hâkimiyetini oldukça zorlaştırmakla birlikte doğal bir koruma sağladığı da düşünülebilir. Sınır boyunca uzanan dağlar 2500-3000 metreye kadar yüksekliğe sahip olup dağlar kütlevi ve birbirinden eşik ve vadilerle ayrılır. Türkiye İran sınırı genellikle dağların zirvelerini takip eder. Mevcut sınır kapıları coğrafyanın elverişli yerlerine inşa edildiğinden bölgenin doğal geçitleridir. Türk İran sınırında Aras nehri ile birkaç akarsu bulunmakta ve bunlar Türkiye'den doğup İran'a akmaktadır. Bölgede orman ise bulunmamaktadir.

Her iki ülkenin sınır civarında bulunan yerleşim yerleri arazi koşullarının elverişsizliği nedeni ile ekonomik açıdan az gelişmiş alanlardır. Ekonomik seçeneklerin azlığı nedeniyle sınır kaçakçılığı yaygındır. Buna bağlı olarak sınır köylerinin nüfusu bölge köylerinden oldukça fazladır (Türkiye tarafında nüfus ortalaması 637 iken sınır köylerinde 869 kişidir). Bölgedeki civar köylerin güvenlik nedeniyle boşaltılmış olmasına bağlı olarak Şemdinli’nin nüfusu artmıştır.

\section{Türkiye'de Sınır Güvenliği Sorumlulukları}

Türkiye'nin İran'la olan sınır güvenliği konusunda yetki, sorumluluk ve bilgi paylaşımı da oldukça parçalıdır. Bu kapsamda sınırda istihbarat toplama ve genel koordinasyondan sorumlu olan kurum Milli İstihbarat Teşkilatı (MIT), giriş ve çıkış yapan kişilerle ilgili kontrol ve önleme araması yapan görevliler polisler, yurda sokulan ve çıkartılan mal ve eşya ile ilgili gerekli sorumlular Gümrük Muhafaza memurları, sınır hattı boyunca 600 metre genişliğe kadar olan alanda sınırların güvenliğinden sorumlu olanlar Kara Kuvvetleri Komutanlığı, sınırdan sokulan hayvan, bitki ve

${ }^{41}$ Ahmet Özgiray, “'İngiliz Belgeleri Işı̆̆ında Türk-İran Siyasi İlişkileri (1919-1938)”, Atatürk Araştırma Merkezi Dergisi, 1995, s. 687-696. 
gıda maddeleri ile ilgili sorunlarda sorumluluk taşıyan ise Gıda ve Tarım Bakanlığı'dır. Genel olarak sınır güvenliği ile ilgili idari sorumluluk ise sınır kapılarının bulunduğu ilin valiliklerindedir. Tüm bu sorumluluklar incelendiğinde Türkiye'de sınır güvenliği ile ilgili bürokratik kuruluşlarının sayısı yirmiyi geçmektedir. 1991 yılında sınır güveliği ile ilgili yapılan düzenlemeler ise bu karmaşayı daha da artırmaktan öteye gitmemiştir. ${ }^{42}$

Türkiye'nin sınır güvenliği ile ilgili kaygı duyanların başında Avrupa Birliği gelmektedir. Nitekim 2013'de ki ilerleme raporunda bu konuya dikkat çekilmiştir. Türkiye sınırları üzerindeki bu yetki karmaşasına dikkat çeken raporun dayandığı bu olgu nedeniyle Türkiye Şengen vizesine dâhil edilmemiştir. AB'ye katılımı sağlanırsa Türkiye'nin sınırları aynı zamanda AB'nin sınırları olacağından mevcut durumun neden AB'yi kaygılandırd1ğ1 daha açık biçimde anlaşılabilir.

\section{Türkiye-İran Sınır Güvenliği Sorunları}

Türkiye ve İran arasındaki sınırın bölgenin coğrafik yapısıyla uyumlu olduğu bu nedenle her iki ülke arasında önemli bir sınır sorunu yaşanmadığı vurgusuna makalenin ilk bölümlerinde yer verilmişti. Bunun dışında Türkiye ve İran arasında sınır güvenliğine konu olacak başlıklar bu makalede göç ve göçmen sorunları ile terör faaliyetleri nedeniyle ortaya çıkan güvenlik problemleri kapsamında ele alınacaktır.

\section{Türkiye İran Arasında Göç ve Göçmen Sorunları}

Türkiye'nin coğrafi yapısı itibariyle tüm sınırlarının yaklaşık \%65'i dağlık alanlardan geçmektedir. Özellikle doğu ve güneydoğuda bulunan sınırlar çoğunlukla dağların zirvesinden geçtiği görülmektedir. Bölgenin bu coğrafi özelliklerine bağlı olarak yaz ayları bile sert iklim koşullarına sahiptir. Bu nedenle Türkiye açısından Doğu ve Güneydoğu bölgesinin sınır denetiminin sağlanması oldukça zordur. Bu olumsuz koşullar doğal olarak sınır ihlallerine olanak sağlar.

Türkiye-İran arasındaki kara sınırı toplam 560 kilometre uzunluğuyla bir yanda ülkenin en uzun ikinci sınırını oluştururken, diğer yanda coğrafi ko-

42 “Türkiye’nin Sınır Güvenliği Sorunu”, Al-Monitor, 2014. 
şulların elverişsizliğiyle birleşerek iki ülke arasında yüksek güvenlik sorunlarına potansiyel yaratmaktadır. Bu nedenle bölge uzun yıllardır kaçakçılık ve yasa dışı sınır ihlallerinin, kontrolsüz göç hareketlerinin mekânı haline gelmiştir. ${ }^{43}$

İçduygu ve Aksel' in çalışmalarına göre 1979 yılında gerçekleşen İran Devriminin ardından bölge İranlıların akınından oldukça fazla etkilenmiştir. Fakat İranlı göçmenlerin çoğu, siyasi nedenlerle ülkelerinden ayrılmak zorunda kalarak Avrupa ya da Kuzey Amerika'ya geçmek isteyen, bu nedenle Türkiye'yi geçiş ülkesi olarak kullanan kişilerden oluşmuştur. Sonuçta komşu ülkelerdeki siyasi ve ekonomik kargaşalar neticesinde yarım milyonu aşkın insan Türkiye'ye girmiştir. ${ }^{44}$

Tablo 1. 2017 Yı11 Aylara Göre Türkiye’ye Giriş Yapan Yabancıların Dağ $111 \mathrm{mi}^{45}$

\begin{tabular}{|l|l|}
\hline UYRUK & TOPLAM (Kişi) \\
\hline Rusya Federasyonu & 607.447 \\
\hline Almanya & 276.577 \\
\hline Gürcistan & 235.148 \\
\hline İngiltere & 184.173 \\
\hline Bulgaristan & 165.359 \\
\hline İran & $\mathbf{1 5 9 . 4 4 5}$ \\
\hline Ukrayna & 155.879 \\
\hline Hollanda & 62.311 \\
\hline Irak & 61.860 \\
\hline Azerbaycan & 56.233 \\
\hline Diğer & 879.862 \\
\hline GENEL TOPLAM & $\mathbf{2 . 8 4 4 . 2 8 9}$ \\
\hline
\end{tabular}

43 İlknur Cihangir, "İkili ve Bölgesel Güvenlik Unsurları ve Türkiye-İran İlişkilerine Yansımaları”, (Basılmamış Yüksek Lisans Tezi), 2010, Çanakkale Onsekiz Mart Üniversitesi, s. 67.

44 Ahmet İçduygu ve Damla B. Aksel, Türkiye'de Düzensiz Göç, Uluslararası Göç Örgütü Türkiye, Ankara, 2012, s. 12.

45 A.g.e. 
Mevcut verilere göre son on yılda Türkiye'ye giriş yapan yabancı say1sında ise kademeli bir artış gözlemlenmektedir. 2006 yılında 18.916.904 olan ülkeye yabancı girişi sayıs1, 2015 y1lı sonunda 34.633.391'e yükselmiş, 2016 yılı sonunda ise bu rakam tekrar azalma eğilimi göstererek 24.686.471 şeklinde kaydedilmiştir.

2015 yılında tüm sınırlardan Türkiye'ye giriş yapan yabancıların menşeleri arasında ilk beşte yer alan ülkeler sırasıyla Almanya, Rusya, İngiltere, Gürcistan ve Bulgaristan olurken; 2016 yılında bu siralama Almanya, Gürcistan, Bulgaristan, İran ve İngiltere şeklinde; 2017 yılı Mayıs ayında ise sirasıly İran, Gürcistan, Almanya, Bulgaristan ve Rusya şeklinde gerçekleşmiştir (Tablo 1). ${ }^{46}$

Türkiye'ye giriş yapan düzensiz göçmenlerin uyruklarında ise ilk sırayı Suriye, Afganistan ve Irak gibi çatışma ya da ağır güvenlik sorunları yaşayan ülkeler almaktadır. İran'ın Tablo 2'de görülen yeri ise orta sıralardadır. Buna karşın düzensiz göçmenlerin yakalandıkları iller içinde en önlerde yer alan Ağrı ili Türkiye-İran arasında yer alan en önemli sınır kapılarından biri olan Gürbulak sınır kapısına ev sahipliği yapmaktadır.

Grafik 2.'de ise 2016 yılında hudut kapılarından yapılan girişlerde sıralamada yer alan ilk on ülkeye yer verilmiştir.

Tablo 2. 2016 Yılında Yakalanan Düzensiz Göçmenler (İlk 10 Uyruk) ${ }^{47}$

\begin{tabular}{|l|l|}
\hline Suriye & 69.755 \\
\hline Afganistan & 31.360 \\
\hline Irak & 30.947 \\
\hline Pakistan & 19.317 \\
\hline Gürcistan & 2.679 \\
\hline Banglades & 2.390 \\
\hline İran & $\mathbf{1 . 8 1 7}$ \\
\hline Özbekistan & 1.648 \\
\hline Myanmar (Burma) & 1.169 \\
\hline Azerbaycan & 1.138 \\
\hline Diğgr & 12.246 \\
\hline Toplam & $\mathbf{1 7 4 . 4 6 6}$ \\
\hline
\end{tabular}

46 Türk Kızılayı Göç ve Mülteci Hizmetleri Müdürlüğü, Mayıs 2017, Göç İstatik Raporu, s. 5.

47 T.C. İçişleri Bakanlığı Göç İdaresi Müdürlüğü Düzensiz Göç İstatistiği. 
Grafik 2. 2016 Yılında Hudut Kapılarında Yapılan Girişler (İlk on ülke) ${ }^{48}$

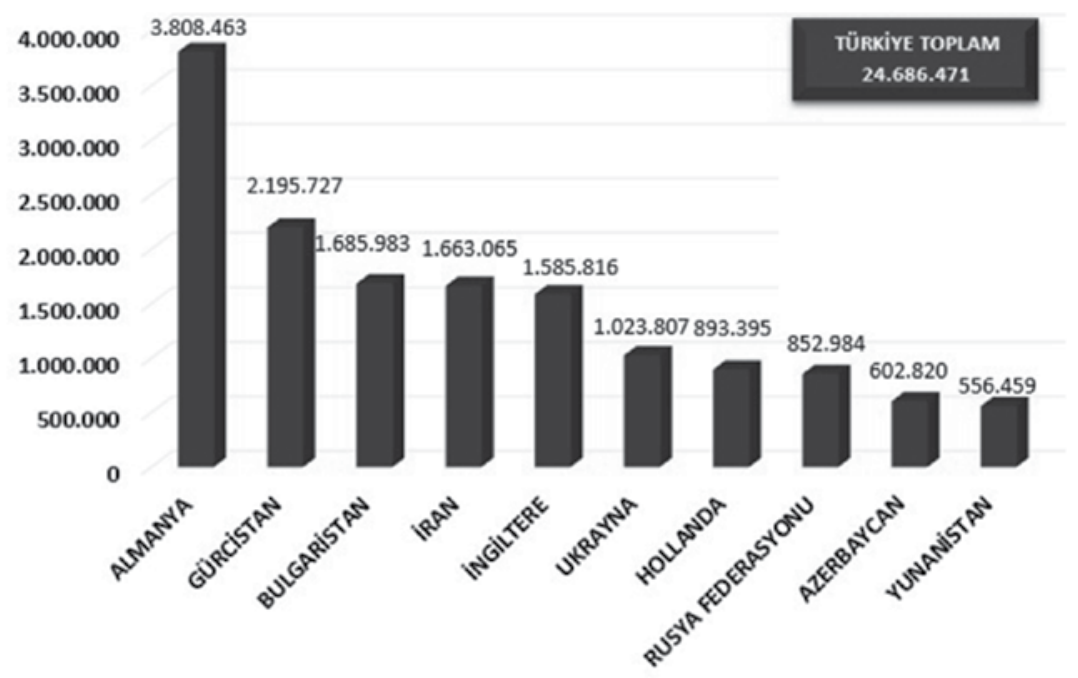

Türk Kızılay’1 Göç ve Mülteciler Hizmetleri Müdürlüğü’nün hazırladığ1 rapora göre 2017 yılında insan ticareti mağduru olabileceği yönünde şüphe duyulan yabancılara karşı valiliklerce verilen ikamet izinleri istatistiğinde yer alan ilk on ülke içinde İranlı bulunmamaktadır. ${ }^{49}$ Yine 2017 yılı istatistiklerine göre Türkiye'de bulunan 50.270 düzensiz göçmen içinde İran uyruklu olanlar 867 kişi ile en alt sıralarda yer almaktadır. Bu rakamlar birlikte düşünüldüğünde İran Türkiye sınırının legal ve illegal göçmen akımı için önemli geçiş noktası olduğu fakat geçiş yapanlar arasında İran uyrukluların göreceli olarak az düzeyde seyrettiği anlaşılmaktadır.

\footnotetext{
48 A.g.e

49 https://www.kizilay.org.tr/Upload/Dokuman/Dosya/88360142_goc-istatistik-raporumayis-2017.pdf, sayfa 10
} 
Grafik 3. 2016 Yılında Hudut Kapılarında Yapılan Çıkışlar (ilk on ülke) $)^{50}$

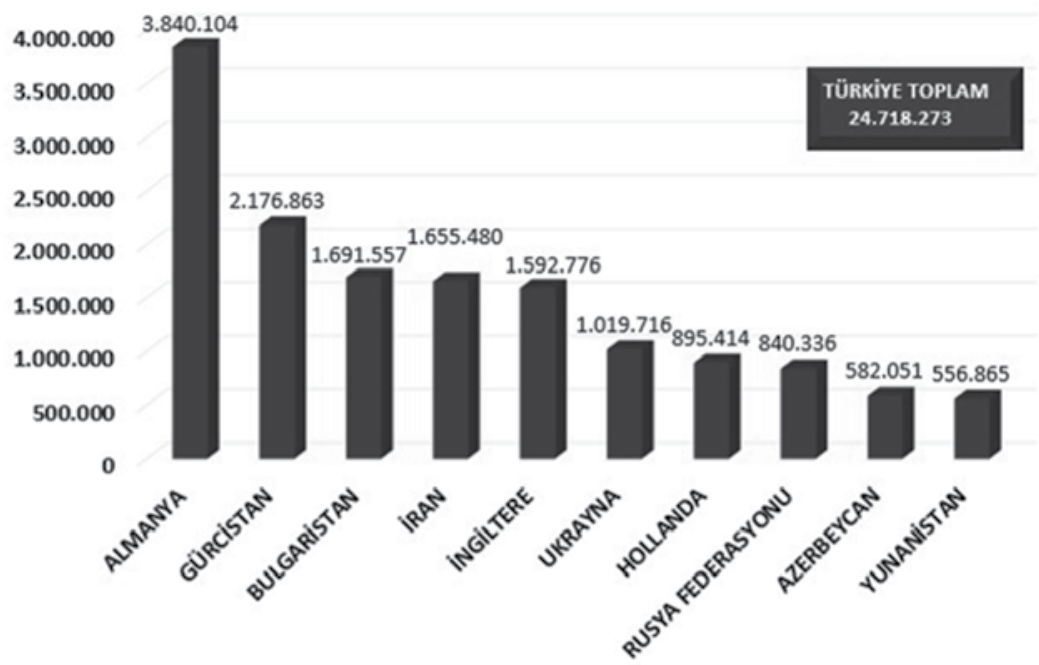

\section{Türkiye-İran Arası Terör Faaliyetleri Bağlamında Güvenlik Sorunları}

Türkiye-İran arasındaki temel sınır sorunlarından biri de her iki ülkede ayrılıkçı faaliyet yürüten PKK terör örgütünün varlığıdır. İran'da PJAK adı altında illegal faaliyet yürüten bu örgüte karşı zaman zaman iki ülke üst düzey görüşmeler gerçekleştirerek ortak tutum belirlemeye çalışmaktadır. Türkiye'nin PKK'ya yönelik operasyonları kesintisiz devam ederken İran'ın PJAK'a olan operasyonları iki ülke arasındaki münasebete göre hızlanıp durağanlaşmaktadır. Ayrıca PKK'nın üst düzey yöneticilerinin zaman zaman İranlı yöneticilerle olan yakın temasları hakkında alınan bilgiler Türkiye için rahatsızlık doğurmaktadır.

Istihbarat çalışmaları sonucu elde edilen bilgilere göre PKK'nın İran'ın Türkiye sınırında Makü, Dambat, Navur, Kotr, Keneresh, Şehidan kamplar1 bulunmaktadır. Bu kamplarda 800-1000 civarında PKK'lı teröristin barındığ 1 düşünülmektedir. Bu teröristlerin zaman zaman Türkiye'ye geçip eylem yaptıkları anlaşıldığından, ya da Türkiye'de Ağrı, Tendürek bölgesinde yapılan operasyonlar karşısında teröristlerin Iran'daki kamplara st-

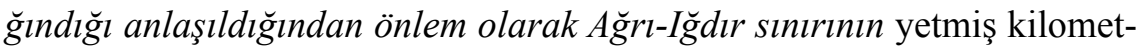

50 T.C. İçişleri Bakanlığı Göç İdaresi Genel Müdürlüğü 
resini duvarla, kalan kısmını ise kuleler, demir tel örgülerle kapatılmasına ve boydan boya 1şıklandırılmasına başlanmıştır.

Iğdır ve Ağrı illeri civarı Türkiye-İran sınırının 144 km. kısmına üç metre yüksekliğinde duvar örülmesi bekleniyor. Bu duvar üzerinde on beş kap1 ve bir güvenlik devriye yolu bulunacak olup kapılarda kurşun geçirmez camlar bulunacaktır. Suriye sınırına ise 688 bin 240 metre duvar örülmüştür.

\section{Türkiye-İran Arası Uyuşturucu ve Sınır Kaçakçılığı Faaliyetleri Bağlamında Güvenlik Sorunları}

Türkiye-İran sınırı transnasyonel terörist ve uyuşturucu trafiği açısından da oldukça problemli görülmekte. Avrupa'ya nakledilen uyuşturucunun \%20 ile 30'unun Afganistan-İran-Türkiye ve Balkanları içeren bir yol üzerinden aktığ1 düşünülmektedir. Orta Asya orijinli uyuşturucunun yaklaşık \%50 ise Rusya ve Doğu Avrupa üzerinde Batıya akmaktadır. ${ }^{51}$ Özellikle Afganistan orjinli metafetamin ve afyon ticaretinin uluslararası geçiş yollarından biri Türkiye-İran sınırıdır. Türkiye-İran arasında ticaret hacminin gelişmesine bağlı olarak malların, kişilerin geçişinin kolaylaştırılması uyuşturucu kaçakçılığ üzerinde olumsuz etki yapmaktadır. Grafik 4'de 2005-2010 yılları arasında Türkiye ve İran arasında gerçekleşen ticaret hacmi ile uyuşturucu trafiği arasındaki ilişki gösterilmektedir. Ayrıca İran'dan Türkiye'ye giren araç sayısı arttıç̧a Türkiye giriş yapan insan sayısı daha da artmaktadır. ${ }^{52}$

51 Rabbit JA, Bacon DR , "Mayo Clinic and The Origins Of Blood Banking", PublMed,2007,82(9), p.117-1118.

52 Behsat Ekici ve Ali Ünlü, ''Increased Drug Trafficking from Iran”, The Middle East Quarterly, 2013 s. 41-48. 
Grafik 4. 2005-2010 Yılları Arasında Türkiye-İran Ticaret Hacmi ve Uyuşturucu Trafiği Arasındaki İlişki ${ }^{53}$

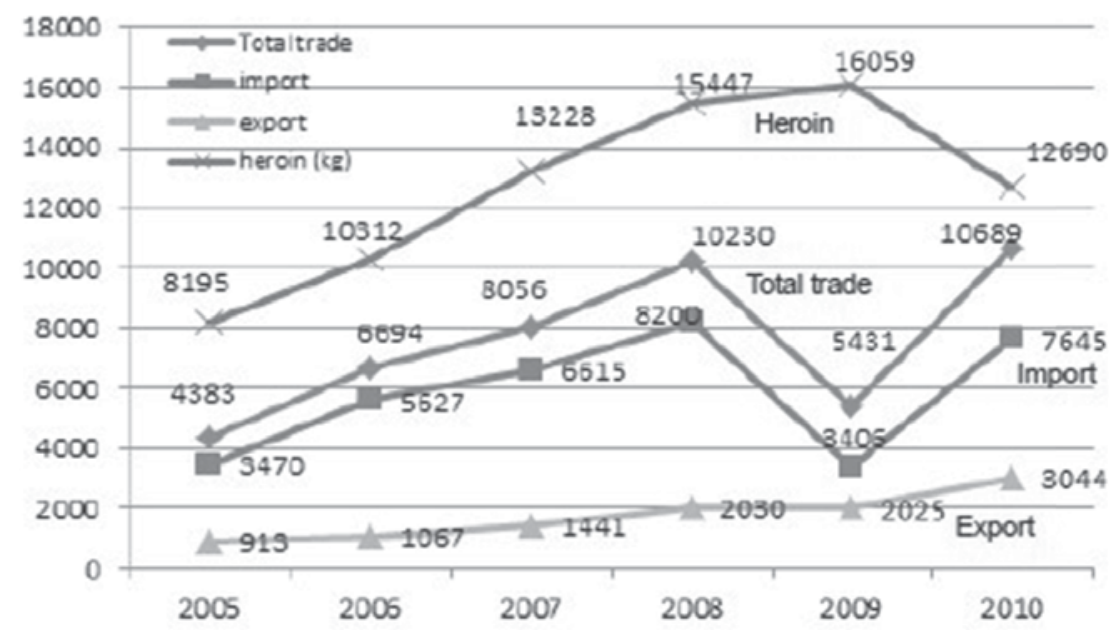

İran'dan Türkiye'ye giriş yapan bir milyona yakın kişinin tekrar ülkelerine dönmedikleri ve Türkiye'de illegal olarak bulundukları sırada çoğunlukla uyuşturucu ile ilgili suçlara karıştıkları saptanmıştır. Kaçakçılık ve Organize Suçlarla Mücadele Başkanlığı'nın verilerine göre Türkiye'de sentetik uyuşturucu işine karışan on dokuz farklı etnik grup içinde \%69 oranı ile İranlılar en geniş gruplardan birini oluşturmaktadır. Eldeki verilerden yola çıkıldığında Asya-Pasifik bölgesinde cereyan eden uyuşturucu trafiğinde daha çok İranlıların sentetik uyuşturucu trafiğini yöneten kişiler olduğu anlaşılmaktadır. Uyuşturucu ticaretinin karayolu ağ 1 ise ağırlıklı olarak İran sınırında bulunan Ağrı, Van, Iğdır ve Hakkâri illerinden oluşmaktadır. ${ }^{54}$

İranlıların Asya-Pasifik bölgesine yönelik uluslararası uyuşturucu ticaretinde Türkiye'yi bağlantı noktası (hub) olarak kullanmaları da diğer bir ilginç durumdur. Ekici ve Özbay'a göre bunun nedeni THY'nin Asya-Pasifik bölgesinde Bankok, Singapur, Jakarta, HonKong, Sidney, Şangay, Pekin, Seul, Osaka ve Tokyo'ya direk uçuşlarının bulunmasından kaynaklanmaktadır. ${ }^{55}$

53 A.g.e s.43

54 Behsat Ekici ve Salim Özbay, ' Iranian Methamphetamine and Turkey: An Emerging Transnational Threat”, Trends In Organized Crime, Volume 16, sy./ 2, June 2013, s. 286-305.

55 A.g.e 


\section{Sonuç ve Genel Değerlendirme}

İran ve Türkiye zaman zaman ittifak ve çatışmalarla dolu uzun bir ortak tarihsel geçmişe sahip iki ülkedir. Her ikisi de dünyanın en fazla geçişkenliğe sahip beş bölgesinden biri olan ve iki kıtayı birbirinden ayıran sınırların iki yanında uzanan coğrafik olarak çok opsiyonlu bir bölgede yer almaktadır. Türkiye küresel ekonomik sisteme tam entegre olmuş bir ülke iken İran politik ve ekonomik olarak kendini Batı'dan izole etmiştir. Ayrıca ortak tarihsel geçmişe sahip olmakla birlikte oldukça farklı sosyal dokuya ve sosyopolitik dinamiklere sahip bu iki ülke birbirini tamamlayan bir görünüm taşımadığından RSCT'de farklı değerlendirilmişlerdir. Buna göre Türkiye Ortadoğu güvenlik kompleksi ile Batı arasında yalıtkan bir ülke rolü oynamaktadır. İran ise Ortadoğu güvenlik kompleksinin lokal bir ülkesi olması sebebiyle bölge içi güvenlik potansiyellerine karşı daha fazla etkileşim içindedir.

RSCT'ye göre Ortadoğu güvenlik kompleksinin güvenlik ve çatışma dinamizmi tarihsel nedenlere dayalı olarak Araplar arası, liderlik yarışına dayalı olarak Araplar arası, Arap ve Arap olmayanlar arası olmak üzere üç sinıfa ayr1labilir. Osmanlı İmparatorluğu'nun son dönemlerinde Arap ve Arap olmayanlar kategorisi Türklere karşı Araplar şeklinde işlerken, günümüzde bu dinamizm İran'a karşı Araplar şeklinde işlemektedir. Dolaysıyla Türkiye doğal olarak Ortadoğu çatışma dinamiğinin içinde artık yer almamakta fakat Bölge ile olan tarihsel ve kültürel bağları nedeni ile farklı bir bölgesel komplekse girmek yerine Batı ve Ortadoğu arasında yalıtkan bir ülke konumunda bulunmaktadır.

İran'ın kendisine komşu diğer ülkelerle olan sınır ilişkileri ve bu ülkelerle olan sınırlarının her iki yakası sosyopolitik ve kültürel doku açısından daha homojen bir görünüm arz ederken Türkiye ile olan sınırı bu açıdan oldukça farklı nitelikler taşır. Bu nedenle İran'ın diğer komşularında bulunan İran uyrukluların sayısı Türkiye'de bulunan İran uyrukluların sayısına göre daha fazladır. Örneğin Irak’ta ve İran'da sınırın her iki yanında bulunan Kürt aşiretler arasında geliş ve gidişler daha yoğundur. İran'ın Körfez Araplarıyla olan ilişkisi ise yine Türkiye'ye göre daha geçişkendir.

Türkiye ve İran arasındaki güvenlik sorunlarına gelince; potansiyel güvenlik sorunlarının bir kısmı Türkiye'deki İranlı muhalifler ve İran'da faaliyet gösteren PKK uzantısı teröristlerle ilgilidir. Tahran Türkiye'nin kendi top- 
raklarında bulunan muhaliflere yeterince sıkı bir kontrol uygulamadığını ileri sürmektedir. Buna karşın İran'ın da topraklarında bulunan PKK mensuplarına benzer biçimde kayıtsız kaldığı Türkiye tarafından ileri sürülmektedir.

Bu bağlamda devam eden karşıllklı suçlamalara rağmen sözü edilen sorunlar Türkiye ve İran arasında sıcak bir çatışmayı körükleyecek nitelikte değildir. İran'ın Batı ile ve özellikle ABD ile olan gerilimli ilişkileri nedeniyle son zamanlarda İran ve Türkiye arasındaki ilişkiler daha dostane olmanın yanı sıra karşılıklı işbirliğine daha açık hale gelmiştir. Özellikle İran'ın nükleer faaliyetleri konusunda İran'a yapılan uluslararası baskının hafifletilmesinde Türkiye çoğunlukla olumlu ve etkin rol oynamıştır. Dolayısıyla Türkiye ve İran ilişkilerinin, Ortadoğu güvenlik kompleksindeki konumlarına uygun olarak gerçekleştiği rahatlıkla söylenebilir.

Türkiye, İran arasında sınır güvenliği sorunları kaçakçılık, yasadışı sınır faaliyetleri ve zaman zaman PKK terör örgütü ile ilgili sorunları içerdiğ $i$ açıklanmıştı. İstatistiksel verilere göre Ortadoğu güvenlik kompleksi içinde uyuşturucu ve illegal kaçakçılık faaliyetlerinde İran uyruklular önemli oranda rol oynamakta, bu nedenle Türkiye'de yakalanan kaçakçılar ve uyuşturucu satıcılar içinde de İran uyruklular da önemli yekûn tutmaktadır. Bunun en önemli nedeni Türkiye İran arasındaki sınırın dağların zirvelerini takip etmesi ve bölgenin topoğrafik özellikleri nedeniyle sınır kontrolünün oldukça zor olmasıdır. Dolayısıyla hem Türkiye hem de İran Orta Asya kaynaklı legal ve illegal göçler için transit ülke konumundadırlar.

Türkiye gerek Batı ile olan iyi ilişkileri ve gerekse $\mathrm{AB}$ katılım süreci nedeniyle bölgedeki diğer ülkelere kıyasla sınır kontrolü ve uyuşturucu kaçakçıları ile müdahale konusunda daha başarılı bir ülkedir. Bununla birlikte Irak ve Suriye' deki istikrarsızlığın bölge güvenliğine olan olumsuz etkileri dikkate alınarak İran-Türkiye sınırına duvar inşa edilerek sınır kontrolü ve güvenliğinin fiziksel olarak daha da artırılması hedeflenmiştir.

Tüm bu olgular ve iki ülke arasındaki mevcut güvenlik sorunları dikkate alındığında dahi İran ve Türkiye arasındaki göç ve güvenlik sorunlarının iki ülke arasındaki ikili ilişkileri olumsuz etkileyecek düzeyde ya da sıcak bir çatışması besleyecek nitelikte olmadığı anlaşılmaktadır. Türkiye İran üzerinden gelen Orta Asya kaynaklı göçler için transit ülke konumundadır. Bu göçmenler içinde İranlılar az bir yekûn tutmakta buna karşın Orta 
Asya orjinli uyuşturucu kaçakçıllı̆ında ise İranlılar başat rol oynamaktadır. Bu durum İran ve Türkiye arasındaki güvenlik sorunlarının daha çok asayiş alanında yoğunlaştığı, ulusal güvenlik riski ise taşımadığı şeklinde yorumlanabilir. Sınır güvenliği konusunda ise her iki ülkede sınır bölgesine yakın vilayetlerin mülki erkânlarının düzenli aralıklarla karşılıklı olarak bir araya gelip görüş alışverişinde bulunup koordinasyonu güçlendirdikleri görülmektedir.

\section{Kaynakça}

Aslan, S., Demirhan, Y., (2015). “Türkiye'nin Sınır Ötesi Göç Politikaları ve Yönetimi”, Birey ve Toplum Dergisi, Cilt:5, Sayı:9, 25.

Birdişli, Fikret. (2017), Teori ve Pratikte Uluslararası Güvenlik, Ankara: Seçkin Yayınları

Buzan, B. Weaver, O. (2000). Regions and Powers The Structure of International Security, Cambridge: Cambridge University Press.

Cihangir, İlknur, (2010). İkili ve Bölgesel Güvenlik Unsurlarl ve TürkiyeIran İlişkilerine Yansımaları, (Basılmamış Yüksek Lisans Tezi), Çanakkale Onsekiz Mart Üniversitesi, 67.

Davison, Roderic H. (1963). "Where is The Middle East?" In The Modern Middle East, (ed. Richard H. Nolte), New York: Atherton, pp:13-30

Davudoğlu, Ahmet, (2002), Stratejik Derinlik, İstanbul: Küre Yayınları

Demirhan, Yılmaz ve Seyfettin Aslan, (2015), “Türkiye'nin Sınır Ötesi Göç Politikaları ve Yönetimi”, Birey ve Toplum, 2015, c.5,say1 9, ss.23-62

Ekici, B. Salim Özbay, (2013). "Iranian Methamphetamine and Turkey: An Emerging Transnational Threat". Trends in Organized Crime, volume 16. number 2. pp.286-305.

Ekici B, A. Ünlü, (2013). ' Increased Drug Trafficking from Iran", The Middle East Quarterly, 41-48.

Gök, G. O.(2016) "Kimin Güvenliğii? Uluslararası Göç-Güvenlik İlişkisi ve Uluslararası Örgütlerin Rolü", KOSBED, Sayı:31, 68-69.

Irwin, Robert, (2008), Oryantalistler ve Düşmanları (çev. Bahar Tırnakçı), İstanbul: Yap1 Kredi Yayınları 
İçduygu, Ahmet ve Damla B.Aksel, (2012), Türkiye'de Düzensiz Göç, Uluslararası Göç Örgütü-Türkiye, Ankara

Jedlitschka, Anja. (2004), Weibliche Emanzipation in Orient und Okzident. Von der Unmöglichkeit, die Andere zu befreien. Würzburg: Ergon Verlag.

Johannsen, Margret. (2006), Der Nahost-Konflikt: Eine Einführung, Wiesbaden: Springer VS.

Karaca, İ. (2016). AB'nin Entegre Sinır Yönetimi Kurumu Frontex'in Rolü ve Türkiye'nin Uyum Süreci, (Basılmamış Yüksek Lisans Tezi), Beykent Üniversitesi, İstanbul,

Kaya, Ahmet. (2005). Avrupa Birliği'nin Yasadışı Göçle Mücadele Politikası ve Türkiye Üzerindeki Etkileri, (Basılmamış Yüksek Lisans Tezi), Ankara Üniversitesi.

Kaya, Ahmet. (2013). "Sınır Güvenliği Paradigmalarındaki Değişim ve Türkiye'nin Sınır Güvenliği Yapısının Analizi”, Uluslararası Güvenlik ve Terörizm Dergisi, sayı:4 (2), ss. 1-12.

Kurt, Selim. (2015). “Toplumsal Güvenliğin Yükselişi”, International Journal of Social Science Studies, say1:37, s.459-476

Lew1s, Bernard. (1968), The Middle East and the West, London: Weidenfeld and Nicolson.

Mandacı, Nazif, Özerim, G. (2013). "Uluslararası Göçlerin Bir Güvenlik Konusuna Dönüşümü: Avrupa'da Radikal Sağ Partiler ve Göçün Güvenlikleştirilmesi”, Uluslararası İlişkiler Dergisi, Cilt 10, Sayı 39, ss.105-130

Miş, N. (2011). "Güvenlikleştirme Teorisi ve Siyasal Olanın Güvenlikleştirilmesi”, Akademik Incelemeler Dergisi, Cilt:6, Say1:2, 347.

Özgiray, Ahmet (1995). "İngiliz Belgeleri Işığında Türk-İran Siyasi İlişkileri (1919-1938)”, Atatürk Araştırma Merkezi Dergisi, 687-696.

Pflitsch, Andreas. (2003), Mythos Orient Eine Entdeckungsreise, Basel: Herder, Freiburg

Rabbit, JA and Bacon DR, (2007) "Mayo Clinic and The Origins Of Blood Banking”, PublMed, 2007,82(9), p.117-1118

People, Columba and Nick Voughan-Williams, (2015), "Securitisation Theory”, Critical Security Studies, Routledge New York, p.97 
Şilibekova, A. (2007). "Orta Asya Bölgesel Güvenlik Sistemine Doğru: Perspektifler”, ICANAS 38, 10'ncu cilt, Atatürk Kültür Dil ve Tarih Yüksek Kurumu, Ankara ss.1319-1326.

Şir, A. Y. (2003). "Bölgesel Güvenlik Kompleksi Teorisi, Enerji Güvenliği ve Rusya”,Uluslararast Sosyal Bilimciler Kongresi, BİLGESAM. ss.346355

Tüysüzoğlu, G. (2013). “Güvenlik İsteminin Dış Politika Oluşum Sürecine Etkisi: Ermenistan-İran İlişkileri’nin Güvenlikleştirme Kuramı Bağlamında Anlamlandırılması", $O A K A$, c8, sayı 16. ss.95-123

Yeşiltaş, Murat. (2015). “İç Savaşta Komşu Olmak Türkiye'nin Suriye S1nır Güvenliği Siyaseti”, SETA Analiz, Sayı:136, s.11.

\section{Internet Kaynakları}

Al-Monitor, "Türkiye'nin Sinır Güvenliği Sorunu", https://www.almonitor.com/pulse/tr/originals/2014/11/turkey-border-security-problem. html, 29.12.2017

Ekodiyalog, “Türkiye'nin Sinırları”,http://www.ekodialog.com/Turkiye_ ekonomi/ turkiyenin_sinirlari_yeri.html, 29.12.2017

T.C. İçişleri Bakanlığı Göç İdaresi Genel Müdürlügü Düzensiz Göç İstatistiği, “'2016 Yılında Yakalanan Düzensiz Göçmenler (İlk 10 Uyruk)”, http:// www.goc.gov.tr/icerik6/duzensiz-goc_363_378_4710_icerik, 01.08.2017.

T.C. İçişleri Bakanlığı Göç İdaresi Genel Müdürlüğü, ”2016 Yılında Hudut Kapılarından Yapılan Çıkışlar", http://www.goc.gov.tr/icerik6/giris-cikis_363_378_4708_icerik, 01.08.2017.

T.C. İçişleri Bakanlığı Göç İdaresi Genel Müdürlüğü, "2016 Yılında Hudut Kapılarından Yapılan Girişler", http://www.goc.gov.tr/icerik6/giris-cikis_363_378_4708_icerik, 01.08.2017.

T.C. İçişleri Bakanlığı Göç İdaresi Genel Müdürlüğü, '2016 Yılında İkamet İzni İle Türkiye'de Bulunan Yabanc1lar”,http://www.goc.gov.tr/icerik3/ikamet-izinleri_363_378_4709, 01.08.2017.

Türk Kızılayı Göç ve Mülteci Hizmetleri Müdürlüğü, “Göç İstatistik raporu”, https://www.kizilay.org.tr/Upload/Dokuman/Dosya/34252135_gocistatistik-raporu-kasim-2017.pdf, 29.12.2017 
Türkiye İstatistik Kurumu, "Genel Çalışma Durumuna Göre Giriş Yapan Vatandaşlar (Türkiye>de ikamet eden), 2009 -2017”, http://www.tuik.gov. tr/PreTablo.do?alt_id=1072, 23.08.2017.

TÜRSAB, (2017). "TÜRSAB 2017 Tahran Turizm Fuar Raporu", https://www.tursab.org.tr/dosya/15825/tahran-turizm-fuar-raporu_15 825_6240747.pdf, 23.08.2017 